\title{
Energy Inputs in Production of Lentil Crop under Different Types of Farming Systems
}

\author{
Pramod Kumar Mishra*, Ashok Tripathi, Himanshu Tripathi and Sheen C. Moses \\ Department of Farm Machinery and Power Engineering, \\ Punjab Agricultural University, Ludhiana, India \\ *Corresponding author
}

\section{A B S T R A C T}

\begin{tabular}{|c|}
\hline Keywords \\
\hline $\begin{array}{l}\text { Partially } \\
\text { mechanized farming } \\
\text { system, Energy } \\
\text { ratio, Energy } \\
\text { productivity etc. }\end{array}$ \\
\hline Article Info \\
\hline $\begin{array}{l}\text { Accepted: } \\
10 \text { September } 2017 \\
\text { Available Online: } \\
10 \text { October } 2017\end{array}$ \\
\hline
\end{tabular}

Keywords

Partially

system, Energy

ratio, Energy

productivity etc.

\section{Introduction}

Energy is integral part to national development process and to provide major vital services that improve human requirements; fuel for cooking, light for living, motive power for transport, and electricity for modern communication. In agricultural sector, its use is in every form of inputs, seed, fertilizer, agro-chemical for plant protection, machinery use for various operation, housing, transport, and processing. Apart from solar energy, production agriculture uses basic additional energy inputs, soil, water, tractive power, chemicals for growth of plants. The amount of energy invested through these inputs and quantity actually used by the plant govern the crop growth and yield during their life cycle.
Singh et al., (2002) has estimated that total energy input Indian agriculture increased by 3.6 times. In modern agriculture, commercial energy sources (fuel, machinery and chemicals) contribute bulk of the energy supplies to the production system. Commercial energy use in agriculture has been increasing since revolution with increasing use of diesel and electricity in farm operations. The share of agriculture in electricity consumption has increased from $3.9 \%$ of the total consumption in 1950-51 to $29.6 \%$ in 1993-94. Total commercial energy use in agriculture increased nearly fivefold with growth rate of $11.8 \%$ between 1980-81 and 1994-95. The share of agriculture in total 
consumption in the country increasing marginally from 3.2 to $5.2 \%$ during the same period. Increase in land productivity and efficient diversification of agriculture for better economic return to the producers will call for significantly higher level of input to agriculture (Mahapatra, 1991).

India, Bangladesh, Nepal and Pakistan contribute to nearly 50 per cent of world lentil production. This region also imports a lion's share of lentil, mostly red, from external sources like Canada, Turkey, Australia, and Syria. However, there are exports and imports within the region. For example, Nepal exports red lentils to both Bangladesh and India, and India exports lentils to Bangladesh. In India, it was cultivated in 1.54 million ha, yielding 4.5 lakh tones (Anonymous 2016). The states of Uttar Pradesh, Madhya Pradesh, Bihar and West Bengal are major lentil producers. Although a number of improved varieties have been developed in India, their adoption was non-significant. Lentils (Lens esculenta L.) are produced on loam soils of 0 to $25 \%$ slope. The aim of the study is to investigate the energy input and output per unit area, energy output-input ratio, crop yield, specific energy, energy productivity, net energy for lentil crop production. Also make a cost and economic analysis for the crop production in study area for two groups of farmers with different level of technology and machinery ownership status.

\section{Materials and Methods}

The study was conducted in Allahabad district $\left(25.45^{\circ} \mathrm{N}\right.$ and $\left.81.84^{\circ} \mathrm{E}\right)$ in the state of Utter Pradesh (U.P.) located at northern part of India at an elevation of 98 meters and stands at the confluence of two rivers, the Ganga and Yamuna. Based on the criteria village Meja, Korawn, and Manda Block of district Allahabad were selected for the study.The soil analysis showed the structure of soil was clay and sandy loam (Anonymous 2010). The data were collected using a face-to-face questionnaire from two groups of 90 farmers growing lentil crop. The agricultural practices of the farmers based on the land holding, economic conditions and irrigation facility available. Based on the cultivation practices surveyed farmers were divided in two groups.

Group I (50 farmers) was using traditional farming system (Bullock operated). They were aware of the new development in the field of agriculture from various media like T.V., Radio, extension office, new paper etc. But those who are using traditional system of agriculture did not adopt partially mechanize system of farming due to financial constraints very small size of land holding and engagement in other jobs. Group II (40 farmers) was using partially mechanized farming system (Tractor operated) (Zangeneh et al., 2010).

The average size of the land holding was 0.5 and 2.3 ha for group I and II farmers respectively. The sample size was determined using a stratified random sampling technique (Yamane 1967).

$\mathrm{n}=\frac{\Sigma\left(\mathrm{N}_{\mathrm{h}} \mathrm{S}_{\mathrm{h}}\right)^{\mathrm{2}}}{\mathrm{N}^{2} \mathrm{D}^{2}+\sum \mathrm{N}_{\mathrm{h}} \mathrm{S}_{\mathrm{h}}^{\mathrm{z}}}(1)$

Where $\mathrm{n}$ is the required sample size; $\mathrm{N}$ is the number of total holdings in the target population; $\mathrm{Nh}$ is the number of the population in the $\mathrm{h}$ stratification; $\mathrm{Sh}$ is the standard deviation in the $h$ stratification, $S 2 h$ is the variance in the $\mathrm{h}$ stratification, D2 is equal to $\mathrm{d} 2 / \mathrm{z} 2$; $\mathrm{d}$ is the precision, where $(\bar{x}-\bar{X})(5 \%)$ is the permissible error and $\mathrm{z}$ is the reliability coefficient $(1.96$, which represents $95 \%$ reliability). The input requirement of lentil production were collected, determined and presented for every questionnaire as per the socio-economic structures of the farms. Inputs in lentil production were machinery, human labour, chemical fertilizers, diesel, and seed. Output 
was lentil (grain) as a product. The energy equivalent of different input and output were used to estimate the energy values (Singh and Mittal, 1992; Kitani, 1999). The human energy input was calculated by multiplying the number of man-hours $\left(\mathrm{h} \mathrm{ha} \mathrm{ha}^{-1}\right.$ by estimated power rating of human labour (MJ $\mathrm{h}^{-1}$ ) (Singh and Mittal, 1992). Other inputs like diesel, seed, and chemical fertilizers used in lentil crop production were transformed to energy value (MJ ha ${ }^{-1}$ ) by multiplying the quantity of the material used in the farms by the energy equivalent of each material. For example chemical fertilizer (nitrogen) energy consumption calculated by multiplying the amount of nitrogen usage $\left(\mathrm{kg} \mathrm{ha}^{-1}\right)$ by energy coefficient of nitrogen fertilizer production (60.60 $\mathrm{MJ} \mathrm{kg}^{-1}$ ); so the result is the energy consumption of nitrogen fertilizer ( $\mathrm{MJ} \mathrm{ha}{ }^{-1}$ ) used in lentil crop production. Also, other energy inputs can be estimated hereby. Diesel pumps were used to lift the irrigation water, so irrigation energy was displayed as gasoline energy. The amount of output energy ( $\mathrm{MJ} \mathrm{ha}^{-1}$ ) estimated by multiplying the lentil yield $(\mathrm{kg}$ $\left.\mathrm{ha}^{-1}\right)$ by lentil crop energy equivalent $\left(\mathrm{MJ} \mathrm{kg}^{-1}\right)$.

Output-Input Energy Ratio = Output energy $\left(\mathrm{MJ} \mathrm{ha}^{-1}\right) /$ Input energy $\left(\mathrm{MJ} \mathrm{ha}^{-1}\right)(2)$

Specific Energy = Input Energy $\left(\mathrm{MJ} \mathrm{ha}^{-1}\right) /$ Grain yield $\left(\mathrm{Kg} \mathrm{ha}^{-1}\right)(3)$

Energy Productivity = Grain yield $\left(\mathrm{Kg} \mathrm{ha}^{-1}\right) /$ Input Energy $\left(\mathrm{MJ} \mathrm{ha}^{-1}\right)$ (4)

Net Energy = Output Energy $\left(\mathrm{MJ} \mathrm{ha}^{-1}\right) /$ Input Energy (MJ ha $\left.{ }^{-1}\right)(5)$

Human labour, machinery, diesel fuel, chemical fertilizers, farmyard manure, chemicals, water for irrigation, and output yield values of lentil crop have been used to estimate the energy output-input ratio, specific energy, energy productivity and net energy. Energy equivalents defined by the
Singh and Mittal (1992) and Kitani (1999) were used for estimation energy in this study. Direct energy constituted human labour and diesel fuel, whereas, indirect energy encompassed farmyard manure, complex chemical fertilizer, chemicals, machinery and water for irrigation.

In the last part of the study, the economic analysis of lentil crop was investigated. Net profit, gross profit and benefit to cost ratio were calculated. The gross value of production, net return and benefit to cost ratio were calculated using the following equations (Mohammadi et al., 2008):

Total Production Value $=$ Yield $\left(\mathrm{kg} \mathrm{ha}^{-1}\right)^{*}$ cost $\left(\$ \mathrm{~kg}^{-1}\right)(6)$

Gross return $=$ Total production value $\left(\$ \mathrm{ha}^{-1}\right)$ - Variable production cost $\left(\$ \mathrm{ha}^{-1}\right)(7)$

Net return $=$ Total production value $\left(\$ h^{-1}\right)-$ Total production cost $\left(\$ \mathrm{ha}^{-1}\right)(8)$

Benefit-cost ratio $=$ Total production value $(\$$ $\left.\mathrm{ha}^{-1}\right) /$ Total production costs $\left(\$ \mathrm{ha}^{-1}\right)(9)$

Productivity $=$ lentil yield $\left(\mathrm{kg} \mathrm{ha}^{-1}\right) /$ Total production costs $\left(\$ \mathrm{ha}^{-1}\right)$

\section{Results and Discussion}

\section{Operation wise inputs and output energy} use in lentil crop production

Operation wise inputs used and output for lentil crop production in the surveyed area, and their energy equivalents with output energy rates and their equivalents are illustrated in Table 1. Total energy consumed in various farm operations during lentil crop production was 7367.64 and 10048.2 $\mathrm{MJ} \mathrm{ha}^{-1}$ for group I and II, respectively. Chemical fertilizer consumes maximum energy $39.29 \%$ for group I and $32 \%$ group II of total energy 
inputs during production period with second highest percentage difference. Energy consumed for irrigation of group I and II was $2.72 \%$ and $9.06 \%$ respectively. The reason behind the difference in maximum percentage of irrigation was due to use of canal by group I, whereas also used electric motor and diesel pump for water lifting. Whereas group II was used diesel pump and electric motor only.

Group I and II used 1226.72 and 1569.73 MJ $\mathrm{ha}^{-1}$ energy for sowing respectively. Harvesting was consumed 985.27 $\mathrm{MJ} \mathrm{ha}^{-1}$ energy for group I and 1105.2 $\mathrm{MJ} \mathrm{ha}^{-1}$ energy for group II farms. Operation wise energy input ratio, percentage use energy and percentage difference for both group are shown in Table 1.

\section{Source wise energy input use in lentil crop production}

Source wise input of energy input is shown in Table 2. Direct source wise energy calculated for Group I was 3909.35 MJ ha ${ }^{-1}$ (52.51\%) and 5732.67 $\mathrm{MJ} \mathrm{ha}^{-1}(58.77 \%)$ for Group II. Indirect source wise energy calculated for Group I and Group II were 3536.06 (47.49\%) and 4021.64 $\mathrm{MJ} \mathrm{ha}^{-1}$ (41.23\%), respectively.
The input energy used as an indirect source was lowest for seed in both groups. Energy input ratio for group I and group II in direct energy was $1: 1.5$ and in indirect energy was 1:1.1 with respect to group $\mathrm{I}$.

Human energy use in both the group has $15.44 \%$ difference. Source wise energy requirement parameters, percentage use energy, ratio and percentage difference are given in Table 2.

\section{Energy output-input ratio}

The energy input and output, yield, energy use efficiency, specific energy, energy productivity and net energy of lentil crop production in the study area were showed in Table 3.

Average yield at farmers field was recorded 1202.99 and $1802.36 \mathrm{~kg} \mathrm{ha}^{-1}$ and calculated total energy output was 16878 and $25287 \mathrm{MJ}$ $\mathrm{ha}^{-1}$ for Group I and II respectively. Energy use efficiency (energy ratio) was calculated as 2.29 and 2.52 for group I and II respectively. The average energy productivity of farms was 0.16 and 0.18 group I and II respectively.

Table.1 Operation wise amounts of inputs and output in lentil crop production

\begin{tabular}{|c|c|c|c|c|c|c|}
\hline Operations & & Energy $r$ & yirement & & Ratio & \% Difference \\
\hline Inputs (MJ ha $\left.{ }^{-1}\right)$ & Group I $^{\mathrm{a}}$ & $\%$ & Group II $^{b}$ & $\%$ & & \\
\hline Land preparation & 1307.64 & 17.75 & 1896.27 & 18.87 & $1: 1.5$ & 1.12 \\
\hline Fertilizer application & 2894.76 & 39.29 & 3215.24 & 32.00 & $1: 1.1$ & 7.29 \\
\hline Sowing & 1226.72 & 16.65 & 1569.73 & 15.62 & $1: 1.3$ & 1.03 \\
\hline Irrigation & 200.43 & 2.72 & 910.23 & 9.06 & $1: 4.5$ & 6.34 \\
\hline Harvesting & 985.27 & 13.37 & 1105.2 & 11.00 & $1: 1.1$ & 2.37 \\
\hline Threshing & 752.82 & 10.22 & 1351.56 & 13.45 & $1: 1.8$ & 3.23 \\
\hline $\begin{array}{l}\text { Total input energy } \\
\text { Output }\end{array}$ & 7367.64 & 100.00 & 10048.2 & 100.00 & $1: 1.4$ & \\
\hline Output (MJ ha ${ }^{-1}$ ) & 16878 & & 25287 & & $1: 1.5$ & \\
\hline Lentil crop (kg) & 1202.99 & & 1802.35 & & $1: 1.5$ & \\
\hline
\end{tabular}


Table. 2 Source wise amounts of inputs and output in lentil crop production

\begin{tabular}{|c|c|c|c|c|c|c|}
\hline \multirow{2}{*}{ Parameters } & \multicolumn{4}{|c|}{ Energy requirement } & \multirow{2}{*}{ Ratio } & \multirow{2}{*}{$\%$ Difference } \\
\hline & Group I & $\%$ & Group II & $\%$ & & \\
\hline \multicolumn{7}{|l|}{ Direct Energy (MJ ha $\left.{ }^{-1}\right)$} \\
\hline Human & 2368.64 & 31.81 & 1597.28 & 16.38 & $1: 0.7$ & 15.44 \\
\hline Bullock & 1540.71 & 20.69 & 0 & 0 & & 20.69 \\
\hline Diesel & 0 & 0 & 4135.39 & 42.40 & & 42.40 \\
\hline $\begin{array}{l}\text { Total Direct energy } \\
\text { Indirect energy }\left(\mathbf{M J} \mathbf{h a}^{-\mathbf{1}}\right)\end{array}$ & 3909.35 & 52.51 & 5732.67 & 58.77 & $1: 1.5$ & 6.26 \\
\hline Seed & 265.4 & 3.56 & 286.57 & 2.94 & $1: 1.1$ & 0.63 \\
\hline Fertilizer/Chemical & 2650.43 & 35.60 & 3056.75 & 31.34 & $1: 1.2$ & 4.26 \\
\hline Machinery & 620.26 & 8.33 & 678.32 & 6.95 & $1: 1.1$ & 1.38 \\
\hline Total Indirect energy & 3536.09 & 47.49 & 4021.64 & 41.23 & $1: 1.1$ & 6.26 \\
\hline
\end{tabular}

Table.3 Energy output-input ratio in lentil crop production

\begin{tabular}{lcccc}
\hline \multicolumn{1}{c}{ Parameters } & Unit & Group I & Group II & Ratio \\
\hline Input energy & $\left(\mathrm{MJ} \mathrm{ha}^{-1}\right)$ & 7367.64 & 10048.2 & $1: 1.4$ \\
Output energy & $\left(\mathrm{MJ} \mathrm{ha}^{-1}\right)$ & 16878 & 25287 & $1: 1.5$ \\
Output-input energy ratio & & 2.29 & 2.52 & $1: 1.1$ \\
Yield & $\left(\mathrm{kg} \mathrm{ha}^{-1}\right)$ & 1202.99 & 1802.35 & $1: 1.5$ \\
Specific energy & $\left(\mathrm{MJ} \mathrm{kg}^{-1}\right)$ & 6.12 & 5.58 & $1: 0.9$ \\
Energy productivity & $\left(\mathrm{kg} \mathrm{MJ}^{-1}\right)$ & 0.16 & 0.18 & $1: 1.1$ \\
Net energy & $\left(\mathrm{MJ} \mathrm{ha}^{-1}\right)$ & 9510.36 & 15238.8 & $1: 1.6$ \\
\hline
\end{tabular}

Table.4 Economic analysis of lentil crop productions

\begin{tabular}{lccc}
\hline Cost and return components & Unit & Group I & Group II \\
\hline Yield & $\mathrm{kg} \mathrm{ha}^{-1}$ & 1202.99 & 1802.35 \\
Sale price & $\$ \mathrm{~kg}^{-1}$ & 1.1 & 1.1 \\
Total production value & $\$ \mathrm{ha}^{-1}$ & 1323.29 & 1982.59 \\
Variable cost of production & $\$ \mathrm{ha}^{-1}$ & 297.74 & 396.52 \\
Fixed cost of production & $\$ \mathrm{ha}^{-1}$ & 158.80 & 198.26 \\
Total production cost & $\$ \mathrm{ha}^{-1}$ & 456.54 & 594.78 \\
Gross return & $\$ \mathrm{ha}^{-1}$ & 1025.55 & 1586.07 \\
Net return & $\$ \mathrm{ha}^{-1}$ & 866.76 & 1387.81 \\
Benefit to cost ratio & & 2.90 & 3.33 \\
\hline
\end{tabular}

$* 1 \$=$ Rs 50

The specific energy of lentil crop production were 6.12 and $5.58 \mathrm{MJ} \mathrm{kg}^{-1}$ and net energy of lentil crop production were 9510.36 and $15238.8 \mathrm{MJ} \mathrm{ha}^{-1}$ for Group I and II respectively. Energy ratio for both groups in input energy, output energy, output-input energy ratio, yield, specific energy, energy productivity and net energy were 1:1.40, $1: 1.15,1: 1.1,1: 1.5,1: 0.9,1: 1.1$ and $1: 1.6$ respectively. 
Economic analysis of lentil crop production

The total cost of production, gross return, productivity and benefit to cost ratio of lentil crop are calculated using equation (6-10) and are shown in Table 4 for both the group. The total production value for Group I was 1323.29 \$ ha ${ }^{-1}$ while in Group II was 1982.59 $\$ \mathrm{ha}^{-1}$. Variable and fixed cost of production was $297.74,396.52 \$ \mathrm{ha}^{-1}$ and 158.8, 198.26\$ $\mathrm{ha}^{-1}$ for group I and group II, respectively. Total production cost in lentil crop for group I was $456.54 \$ \mathrm{ha}^{-1}$ and $594.78 \$ \mathrm{ha}^{-1}$ for group II. Gross return in group I was $1025.55 \$ \mathrm{ha}^{-1}$ whereas in group II 1586.07 $\$ \mathrm{ha}^{-1}$. The net return in group II was $1387.81 \$ \mathrm{ha}^{-1}$, higher than group I $866.76 \$ \mathrm{ha}^{-1}$.

The total operational energy under traditional farming system (Group I) and partially mechanized farming system (Group II) were also evaluated which was more on case of Group II as compared to Group I. Source wise energy was also having the similar rise in case of Group II. Energy consumption was highest in fertilizer application in both the group which was $39.29 \%$ and $32 \%$ for Group I and II respectively. Output-input energy ratio under traditional and partially mechanized faming systems was 2.29 and 2.52. The operational specific energy in traditional and partially mechanized system was 6.12 and $5.58 \mathrm{MJ} \mathrm{q}^{-1}$. Energy productivity $\left(\mathrm{kg} \mathrm{MJ}^{-1}\right)$ for Group I is 0.16 and 0.18 for Group II. The yield in Group II system is more than Group I system because of more use of energy. Specific energy, output-input energy ratio and energy productivity of group I and group II were also calculated and discussed. In an economic analysis of group I and II the benefit to cost ratio was 2.90 and 3.33 respectively. The net return of group II was found more than group I. This study shows that economically, partially mechanized farming system is more profitable than traditional farming system. So, traditional farming system should be changed with the partially mechanized farming system in lentil crop production.

\section{References}

Anonymous, 2010. Zonal project directorate Kanpur; District profile http://zpdk.org.in/sites/default/files/districtp rofile (2-2-10).pdf.

Anonymous, 2014. Production, yield and area of cotton. www.indiastat.com. A site registered with main library, Punjab Agricultural University, Ludhiana (Date of visit: $28^{\text {th }}$ December, 2014).

Bockari - Gevao, S.M., Wan Ishak W I, Azmi Y, Chan C W. 2005. Analysis of energy consumption in low land rice-based cropping system of Malaysia. SciTechnol27 (4):819-26.

Demircan, V., Ekinci K; Keener H M; Akbolat D; Ekinci C. 2006. Energy and economic analysis of sweet cherry production in Turkey: a case study from Isparta province. Energy Convers Manage 47:1761-9.

Erdal, G., Esengun K; Erdal H; Gunduz O. 2007. Energy use and economic alanalysis of sugarbeet production in Tokat province of Turkey. Energy 32: 35-41.

Esengun, K., Erdal G; Gunduz O; Erdal H. 2007. An economic analysis and energy use in stake-tomato production in Tokat province of Turkey. Renew Energy 32:1873-81.

Faidley, L.W., 1992. Energy and agriculture. In: R.C. Fluck (Ed), Energy in Farm Production, Elsevier, Amsterdam: 1-12.

Franzluebbers, A.J., Francis C A. 1995. Energy output-input ratio of maize and sorghum management systems in Eastern Nebraska. AgricEcosyst Environ 53(3):271-8.

Karale, D.S., Khambalkar, V P; Bhende S M; Sharddha B A; Wankhede P S. 2008. Energy economic of small farming crop production operations. World Journal of Agricultural Sciences 4 (4): 476-482.

Kitani, O., 1999. CIGR Handbook of Agricultural Engineering Energy and Biomass Engineering. vol. 5; 1-11. St Joseph, MI: ASAE Publication.

Mandal, K.G., Saha K P; Ghosh P K; Hati K M; 
Bandyopadhyay K K. 2002. Bioenergy and economic analysis of soybean-based crop production systems in central India. Biomass and bioenergy. 23(5):337-45.

Mohammadi, A., Omid M. 2010. Economical analysis and relation between energy inputs and yield of greenhouse cucumber production in Iran. Appl Energy 87(1):1916.

Mohapatra, P.K., 1991. Energy studies in cropping system in Lateritic soil of Orissa. AMA 22(1): 49-52.

Mrini, M., Senhaji F; Pimentel D. 2001. Energy analysis of sugarcane production in Morocco. Environ, Dev Sustainability 3: $109-26$

Pimentel, D., 2006. Impacts of Organic Farming on the Efficiency of Energy Use in Agriculture. An Organic Center State of Science Review. https://www.organiccenter.org/reportfiles/ENERGY_SSR.pdf.

Rathke, G.W., Diepenbrock W. 2006. Energy balance of winter oilseed rape (Brassica napus L.) Cropping as related to nitrogen supply and preceding crop. Eur J Agron 24:35-44.

Safa, M., Tabatabaeefar A. 2002. Energy consumption in wheat production in irrigated and dryland farming. In: Proceedings of International Agricultural Conference, Wuxi, China. November 2830.

Sartori, L., Basso B; Bertocco M; Oliviero G. 2005. Energy use and economic evaluation of a three year crop rotation for conservation and organic farming in NE Italy. Biosystems engineering 91(2): 24556.

Singh, H., Mishra D; Nahar N M. 2002. Energy use pattern in production agriculture of a typical village in Arid Zone, India-Part I.
Energy Conversion and Management 43(16):2275-86.

Singh, S., Mittal J P. 1992. Energy in production agriculture. First edition; 1-15. Mittal Publications.

Stout, B.A., 1990. Handbook of Energy for World Agriculture. Elsevier Applied Science, London.

Triolo, L., Unmole H; Mariani A; Tomarchio L. 1987.Energy analyses of agriculture: the Italian case study and general situation in developing countries. In: Third international lsymposium on mechanization and energy in agriculture, Izmir, Turkey; $p$. 172-84. October 26-29.

Tripathi, H., Chandel NS, Tripathi A, and Mishra $P$ 2015. Energy Use and Economical Analysis for Pea Production, Madras Agric. J., 102 (4-6): 196-200

Tripathi, H., Chandel NS, Tripathi A, and Mishra $\mathrm{P}$, 2013. Energy Use and Economical Analysis for Green Gram Production under Different Farming Systems in Northern India. Agricultural Engineering Today (AET), Vol. 37(3), Pp 27-32.

Tsatsarelis, C.A., 1991. Energy requirements for cotton production in central Greece. J AgricEng Res 50:239-46.

Yadav, R.N., Singh R K P; Prasad S. 1991. An economic analysis of energy requirements in the production of potato crop in biharsharif block of nalandadistrich (Bihar). Econ Affair Kalkatta 36:112-9.

Yamane, T., 1967. Elementary sampling theory. New Jersey, USA: Prentice Hall Englewood Cliffs;

Zangeneh, M., Omid M; Akram A. 2010. A comparative study on energy use and cost analysis of potato production under different farming technologies in Hamadan province of Iran. Energy 35: 2927-2933.

\section{How to cite this article:}

Pramod Kumar Mishra, Ashok Tripathi, Himanshu Tripathi and Sheen C. Moses. 2017. Energy Inputs in Production of Lentil Crop under Different Types of Farming Systems. Int.J.Curr.Microbiol.App.Sci. 6(10): 971-977. doi: https://doi.org/10.20546/ijcmas.2017.610.117 